\title{
The Dynamics of Representing Nepal's Struggle for Modernization: from Nepalization to Fatalism
}

\author{
Gaurab KC and Pranab Kharel
}

\begin{abstract}
This article examines the popular as well as controversial work Fatalism and Development: Nepal's Struggle for Modernization (1991) by anthropologist Dor Bahadur Bista. The authors historically chart out and evaluate the writing trajectory of Bista. The paper focuses on Bista's consistent pitching for fatalism to be the root cause of underdevelopment in Nepali society starting with his writings in the 1960s, even though he may be using different terms to refer to the process. He pointed out certain groups close to the power structures including priestly Brahamins to be responsible for the underdevelopment and fatalism. His iconoclastic stance on the value system revolving around the power centers found many takers in the changed context of Nepal after 1990. This was furthered by his silence on the similar acts of other cultural groups.
\end{abstract}

Keywords: Dor Bahadur Bista, Fatalism and Development, Nepalization, Brahmin, caste, ethnicity, unpublished report 


\section{Introduction}

\section{Mapping Dor Bahadur Bista and his Work ${ }^{1}$}

This paper contextualizes the book Fatalism and Development: Nepal's Struggle for Modernization (F\&D)(1991) by anthropologist Dor Bahdur Bista ${ }^{2}$. In this process the paper also evaluates his other relevant writings. Here, our objective is twofold - first to pin down the genesis of Bista's writings where we have charted out what he produced at various times having been associated with different institutions like American Aid agencies, Center for Nepal and Asian Studies (CNAS) and his engagement with Panchayat ${ }^{3}$ itself. Our second objective is to understand the making of the book $F \& D$. Therefore, we believe the book cannot be judged alone until and unless we understand the entire career or writing trajectory of Bista - as he was a self-trained anthropologist making a mark during a post Rana period - stepping both into the realm of Panchayat and the development arena of Nepal. The authors in the paper claim, Bista penned for different audiences at different times and was undergoing change in his positions on the issues of Brahmins and their relationship with Nepali structure.

In line with Max Gluckman thesis that "the production of knowledge is a social process mediated by and through individuals" (quoted in Uberoi et al, 2007:23) our attempt is also to enquire and investigate his writings by locating it in time and the transition Bista

1. The paper was first presented in the one-day workshop "Debating Development in South Asia: Revisiting Dor B. Bista's Fatalism and Development 25 Years Later" jointly organized by Martin Chautari, Central Department of Anthropology, Tribhuvan University and Department of Sociology, South Asian University, New Delhi on 29 December, 2016.

2. To get a further introduction of Dor Bahadur Bista see 'Bibliography of Social Scientific Writings of Dor Bahadur Bista' (2013), compiled by Gaurab KC and Pratyoush Onta. This is uploaded in Martin Chautrai's website and can be accessed at www.martinchautari.org.np or in the book Anthropology of Nepal: A Compilation of Dor Bahadur Bista's Articles (2015, pp.138-142).

3. Panchayat was a party-less political system emphasizing governance, development and decentralization under the guidance of constitutional absolute monarchy. In terms of governance structure the country was divided into five development regions and four tiers of government-Village Panchayat, District Panchayat, Town Panchayat and Centre. 


\section{2| Gaurab KC \& Pranab Kharel}

underwent personally. Bista belongs to the first generation of Nepali intellectuals in the post Rana period. In one of his writings a noted Nepali scholar of the time Kamal Prakash Malla had mentioned "Besides for last half a century the educated and privileged Nepalese have always found the civil service, together with teaching, as the only alternative avenues of employment to farming and shopkeeping" (1979:171).

Bista was more than what Malla had remarked. The anthropologist had experienced different spheres of Nepali public life. After completing his one-year diploma in Indian ethnography from School of Oriental and African Studies (SOAS), London, in 1961 and returned to Nepal a year later. Back to home he obtained various positions from research specialist to USAID to counsel general to Lhasa, special officer for planning, secretary of remote areas development committee, special officer, investigative bureau at Royal palace, executive director at CNAS, chairman of the department of anthropology/sociology and many more. He produced various writings during his tenure in these institutions. $F \& D$ was published in 1991, a transition period in the Nepali history.

As soon as the book was published it drew attention of the larger audiences consisting from varied walks of life, including both swadesis and bidesis. The book has been reprinted many times, oft cited and gained popularity among the students, researchers, academicians, developmentalists, activists, and all kinds of professionals interested in Nepali society and culture. As stated by an anthropologist Don Messerschmidt "This book was an assigned reading for all the people working in the United Nations to Nepal and I think once a month they had a seminar and discuss the book"4.

Also, the book has been highly criticized for its thesis - that Nepal remained underdeveloped owing to its proclivity for fatalism. Many commentaries and reviews have been both for and against the book (see Dahal 1990, Macfarlane 1990, Sharma 1991, Pahari 1992, Malla 1992, Kamata 1999). The idea which Bista champaioned during 1980s was advocated and manifested in the book especially Bahunbad, Chakari and Aafnomanche has become mantra to many of those working in Nepal. Bista's academic writings can be situated in a different historical period from late 1950s to mid1990s. In doing

4. Interview with Don Messerschmidt, 2011. Messerschmidt had been interviewed in 2011 by Gaurab KC and Sachin Ghimire for the documentary they were jointly making on Dor Bahadur Bista. 
so, his perceptions and ideas can be mapped out in how he framed his ideas and portrayed the Nepali society and culture.

In the course of this time if we evaluate his work especially from 1960s to early 1970s his works are quite descriptive and are the reflections of his personal observations wherever he had travelled, affiliated with or worked for. In the 1980s his writings appear to veer increasingly in the direction of analyzing Nepali society through structural dimensions. In attempting to highlight the structural dimensions, Bista focused on the contestation of values and cultures of Nepali society. He believed the increasing focus on ethnic dimension was altering the roles and positions occupied by both individuals and institutions in Nepali society. This is evident from the conclusions Bista draws from an unpublished report he prepared for CNAS on ethnicity.

However, a look at Bista's writings gives one an impression that from the very beginning of his academic writing he was preoccupied with the structural component of Nepali society. This is reflected in the writings such as People of Nepal and other short articles.

Going back to the evaluation of Bista's writing through different lenses the issue of national integration appears as a recurrent theme. Throughout his writings he has focused on the idea of cultural link between various groups that migrated to Nepal at different periods. However, he is also presenting competing counter narratives portraying fissures and possibility of disjuncture within the agency ${ }^{5}$ and structure of Nepali society. For instance, in People of Nepal he sounds very critical of hill Brahmins and Chhetris dominating the political economy and the cultural sphere influencing non-Hindu groups who had to follow those traits in line with Sanskritization.

In addition to this Bista is also communicating with different audiences in the language and the tone palatable to them. On the one hand Bista is critical of institutions such as Chakari and Aafno Manche but on the other hand he's appreciative of the institution of Monarchy which in turn is the fountainhead of these cultural values. Monarchy had been an important institution in shaping the cultural politics of Nepal. It promoted values that Bista was critical

5. Agency refers to the ability, capacity, and condition of acting to make difference in a situation implying the autonomous action to define and change particular condition. 


\section{4| Gaurab KC \& Pranab Kharel}

of including the institution of Chakari. He is all praise for the King whom he considers the focal of national unity even while sounding contradictory by stating that the apparatus around King engaged in Chakari. He has, instead, argued for the continuation of the institution of the Monarchy.

For a long time to come, the position of the monarch as a symbol of unity and national sovereignty will be very important and crucial in the development of a national society which comprises so many different ethnic, cultural and linguistic communities. (1991, p. 115)

He attempts to provide a socio cultural, historical and ethnographical overtone in his writings based on the idea of consensus as the hallmark of Nepali society by pointing out changes in the different epochs that Nepali society underwent. For this, Bista uses different historical sources in the article including certain texts and oral narratives, and observations. For example, Bista cites the work of Dhanbajra Bajracharya concerning the inscriptions of the Licchavi period. Similarly, references are made to Dibya Upadesh of Prithivi Narayan Shah edited by Yogi Narharinath. During his formative period, he stressed on national integration and promoted ideas like heterogeneity, diversity, plurality, syncretism, and coined terms like Nepalization, which were based on concepts of integration, consensus, unity and national cohesion among denizens who migrated from different parts of the world to Nepal.

However, Bista was upset with various ethnic organizations formed in the late 1980s which he feared would weaken the Nepali national integration. These arguments can be found in his unpublished report prepared for CNAS in 1985. This by no means indicates that he was against particular ethnic groups. But, he was critical of identity politics being played out by these organizations. Bista argued that formation of such organizations would weaken the national integration. He seems to have veered into different mood and thinking between late 1980 s to early 1990 s, and thereby crystallizing his castigating position towards the dominant caste groups. In the latter part of his career (from late 1980s) he adopted a critical approach in characterizing and analyzing Nepali society and culture particularly confining to social structure and the contradictions it inherits and manifests.

The paper will comparatively evaluate some of his writings 
Dhaulagiri Journal of Sociology and Anthropology Vol.11, 2017|135

especially 'The process of Nepalization' (1982), unpublished report Ethnicity: Its Problems and Prospects (1985), Structure of Nepali Society (1989) and $F \& D$, published in early 1990 s.

\section{Writing between 1950s to 1970s}

Bista's writing career begins from 1950s soon, after he assisted a professor from School of Oriental and African Studies (SOAS), Christoph Von Furer Haimendorf ${ }^{6}$. Once Haimendorf left Nepal Bista published four short articles. Two of them were in Nepali and the other two were in English. All those four articles were synoptic description of his observations made about the Northern border region of Nepal, Solu Khumbu.

The two Nepali articles published during 1957 and 1958 were about the documentation of Sherpa folklores entitled 'Ramailo Khumbu ra Kehi Sherpa Lok Git' Dafechari 6(5) and 'Jilla ParichayaSolu Khumbu' Vikash 1(4). The former is a description of the place and the song culturally rooted within the region whereas the second article consists of snapshot profile of the district. The other two short English articles published in the year 1958 in the educational journal Educational Quarterly were titled as 'Educational Problems in the Northern Border Areas of Nepal' and 'Report of an educational factfinding excursion to North-East Nepal'. All the mentioned articles are the portrayal of his observations made during the tour as a teacher in the Norman School where he recorded the district profile, documented Sherpa folklores and prescribed ways of making the school function effectively in the region. These published works, especially two of the English articles made it easy for Bista to enlarge his network and project a career as an intellectual in the post Rana period.

Upon Bista's return to Nepal in 1962, King Mahendra was ruling the country and had established the socio-cultural-political system called Panchayat. US aid agencies were functioning in Nepal in collaboration with the regime. Bista worked with USAID as a research specialist between 1963 to 1968. During this time,

6. Haimendorf was an Austrian born anthropologist. He came to India during 1930s and did an extensive fieldwork on Nagas during the Nizam government. He came to Nepal in 1953 and did preliminary studies on Sherpa for three months. Then, he visited again in 1957. During this trip he was assisted by Dor Bahadur Bista. 


\section{6| Gaurab KC \& Pranab Kharel}

he prepared some reports for USAID and was also a Nepali tutor for Peace Corps visiting the country as development volunteers. In addition to this he also produced some short articles in both Nepali and English magazines and journals.

In 1967 when his book People of $\mathrm{Nepal}^{7}$ was published by then His Majesty's Government, Ministry of Information and Broadcasting he got recognition as a professional anthropologist writing from Nepal. This monograph was a descriptive account categorizing the Nepalis within caste and ethnicity. The book was widely received both inside and outside Nepal. During the same time he also worked closely with Nepal government undertaking many responsibilities. His experience with the bureaucracy was reflected in the two short articles he contributed to the edited volume in the year 1971- 'Administration of Development Programs in the Himalayan Area' and 'Frustration in Nepali Bureaucracy'. Bista's criticism of the crony bureaucracy which is referred in F\&D can be traced to the two aforementioned articles.

After spending some years in bureaucracy, Bista returned to academia in late 1970s following his appointment as an Executive Director of Center for Nepal and Asian Studies (CNAS) in Tribhuvan University (TU) by King Birendra. He also held the position of professor of anthropology in the same institution.

\section{Approaching F\&D}

\section{Writing in the1980s}

During 1980s, Bista seems more interested in evaluating and analyzing the structural components of Nepali society rooted in the existing values and how it functions within the larger socio cultural setting. In his writings published in early 1980s, Bista showed proclivity for the issue of national integration emphasizing on unity in diversity. For instance, in 'Process of Nepalisation' (1982), too Bista stressed on the idea of national cohesion and introduced the term Nepalization. Bista argues:

There have been a number of studies which view the Nepalese

7. After the first edition rest of the edition were published from Ratna books. The book was translated into Nepali and was published from Sajha Prakshan in 1972. Similarly, in 2002 Himal Books published its translated version with the short introduction by Harka Gurung. 
world from a monocultural-linguistic perspective for the simple reason that this is much easier to do. This has often encouraged an emphasis on isolated, exclusive views of communities rather than a search for trends of openness, acceptance, adaptability and social understanding. (1982, p. 2)

He argues Nepal has given opportunity to many outmigrant's to settle here at various course of time. Those settlers migrated both from the Indo-Gangetic and Tibeto- Burman region. And it is only the Nepalization factor that brought them closer. The theme implies a monolithic conglomeration and a process of becoming Nepali both temporally and spatially - former referring to the various waves of migration from both South and North and latter indicating the mobility initiated by King Prithivi Narayan Shah in the process of furthering the idea of nation building. Bista argues

The origins of the Nepalese people of today are diverse, and Nepal is perhaps one of the rarest countries in the world if we consider its smallness in area and its largeness in diversity of people and their integration. (1982, p. 17)

Like others Bista also advocated for the notion of 'diversity' and for him, integration itself is the process of Nepalization. This was similar to what he emphasized in People of Nepal along with the Nepalization article. Similar themes are reflected in the articles Hindu Kingdom and its Social Aspects (1977/1980), Rastriya Ekata (1977), The People (1973). Similar arguments has been made by his contemporary Nepali scholars like Prayag Raj Sharma in 'Hindu Tribal Interface' (1978) and Kamal Prakash Malla's introduction in his edited volume titled Nepal A Conspectus (1980) to mention few. For instance, Malla states:

In the whole history of Nepal ancient or medieval, there has never been an upheaval or crisis rooted in social bigotry, rivalry or intolerance. Coexistence and mutual tolerance have been the twin formulas of social harmony in Nepal since the dawn of its recorded history. In fact, the attitude of acceptance and assimilation has been the all-pervasive stimulus for the flowering of Nepalese culture. (1980, p. III)

Similarly, in the Nepalization article too Bista locates the emergence of Nepali society in its historical evolution. Bista accredits King Prithivi Narayan Shah's action of unification in strengthening 


\section{8| Gaurab KC \& Pranab Kharel}

the process of integration and expanding Nepalization further which united the Nepalis in one homogeneous and monolithic category. According to Bista, the process of unification not only unified the geographical boundaries but also integrated the people and tied the culture closely. This became possible through Nepalization process. Some of his contemporaries critique him for not being clear in the idea for what he had popularized. But, this writing clearly hints Nepalization as a historical process of change at various times which focuses on integration, intermingling and sharing of collective values. For Bista:

Nepal's entire history is one of syncretism of different cultures, religions, languages and people...people have gone back to the natural process of integration and syncretisation of styles, cultures and languages rather than adopt completely a borrowed form of culture and way of life. (1982, p.1)

Within this conglomeration and integration, the gluing factor was harmony and peaceful coexistence among the various peopleof different racial origin-- rather than conflict, and cleavages. He argues that whatever the contestations and conflict took place here were not homegrown but had been imported from the Indo Gangetic plains. During the Medieval era when the Newar King Jayasthiti Malla institutionalized the caste system along the line that existed in the Indo Gangetic plains by inviting Sanskrit scholars from Banaras, this stratified the Kathmandu valley society. This set the ball rolling for future generations of Nepali rulers to follow suit. However, in the latter period of $1980 \mathrm{~s}$, Bista was trying to advocate change but was caught between status quo and counter-change, which was a recurrent phenomenon of the period ${ }^{8}$.

In his essay 'Structure of Nepali society', he reiterated his subversive position and struck at the cultural values that had been structured in Nepali society prevalent within everyday parlance in the form of hierarchy and chakari. He also disapprovingly highlights some actors who advocate for maintaining such values.

The issue of national integration seems to be of paramount importance to Bista. Surprisingly, he also portrayed himself in a

8. The period witnessed several changes including the much important referendum on the status of Panchayat. These changes led to opening up of the polity to a larger extent. But, there were equally competing constituencies in the regime of the day who were the votaries of status quo. 
critical direction condescending certain groups such as priestly Brahamins, Janajatis and Madhesi caste groups. In his unpublished report Ethnicity: Its Problems and Prospects (1985) prepared for CNAS, he highlights how the ethnic organizations were being formed for the political motives and the issue being ethicized, hinted on its future challenges with its threat to the national integration and provided recommendations to counter those threats. In this fifty-page report he has argued that the change of modernization taking place in Nepal has completely disturbed its peace, stability and traditional norms. This resulted in the process of national disintegration. Its direct impact was visible in the inter-ethnic tensions. Different groups started forming their own alliances and the uncontrolled migration in the Tarai from the India has further expanded the conflict creating the bipolarity between Pahadi and Madhesis. He also cautioned that very soon in future the serious conflict between the Pahadi and Madhesis is going to take place which will be worse than the simmering conflict with Janajatis. In this context Bista's Nepalization process experiences rupture as ethnic discourse gains ground. As he points out:

The issues of ethnic, religious, linguistic, or regional conflict are beginning to become increasingly pervasive, intertwined and interrelated with economic, political and development issues of the country. Strong sentiments have already been aroused among different communities, exemplified by founding of the Mongoloid People's Association, the Bhintuna festival, the Tarai Congress, the Sadbhavana Parishad, etc. (1985, p. 10)

For him these organizations were formed instrumentally to achieve a political end. The natures of these organizations were more political than cultural. This has been never seen previously in our history. As he states

In a system where political parties are not allowed to function openly the most obvious alternative means for achieving political ends can only be ethnic, cultural, linguistic or professional organizations. Their professed objective is always cultural, social and sometimes economic. But in effect the same organizations are used for political purposes by certain ambitious individuals. The various associations formed with the professed objective of cultural promotion sometimes show political overtones. The examples are Langhali association of the Magars; Tamu Dhim of Gurungs; 


\section{0| Gaurab KC \& Pranab Kharel}

Thakali Sewa Kendriya Samiti and Thakali Yuva Parivar of the Thakalis; Rai Limbu Samaj; the attempt to organize the Brihad Mongoloid Samaj; Tharu Kalyan Karini Samiti; Maithali Sahitya Parishad; the Sadbhavana Parishad; and Anjuman Islah.... In other words the interest is not in cultural or linguistic identity. The real interest seems to be political. And in the absence of any viable means for mobilizing and articulating collective action, politics is increasingly tending to fall upon ethnic, cultural and linguistic groups. The electoral process is exacerbating this process. It is much easier to attract votes with slogans of communal nature than with those of national integration. This becomes very common when there is a shared belief that one's own group has been underprivileged or has been exploited by others. (1985, pp. 11-15)

The contradiction of Bista towards what constitutes nationalistic element and what is anti-national is best reflected in his outlook towards the Madhesi community in this report. On the one hand he was criticizing the policy of the state to push for the mono language of Nepali and the attire of daura suruwal as the only national language and dress. On the other hand, he sounds alarm bells and argues against recruiting Yadavs and Rajputs in the Nepal army. This contradiction is also indicative of his position vis-à-vis different audiences that he would like to cater to. By stressing on the idea of discrimination in terms of language and dress pattern Bista is communicating with that section of Nepali society which is voicing itself against the monolithic narrative of then state. But, on the other hand he is also fearful of 'inundation' of Tarai with recent migrants from across the border, which could be interpreted as an attempt to placate votaries of state-centric nationalism.

In the late $1980 \mathrm{~s}$, one could observe explicit reiteration of Bista's argument that fatalistic attitudes in Nepali society were hampering its progress. The period was tumultuous both nationally and globally where traditional power structures were being questioned. His 1989 article 'Structure of Nepali Society' could be a point of reference. Bista critically delves in outlining the cultural aspects of Nepali society rooted in its structure. In this article Bista attempts to evaluate Nepali society within the concept of tradition and modernity by connecting it within the broader themes and aspects of Nepali society where he advocates for the idea of time-'modernization' and finds the structured cultural values as a major 
setback for the modernization and development. Making an ideal he compares and contrasts the cultural values of outsiders. Bista states

There is nothing in Nepali values at the present moment which is comparable to the values of work ethics of the Protestant societies of the West, nor anything like the social pressure of the Japanese society to achieve and succeed (1989, p.181).

In the article, where he argues different from the Nepalization piece, Bista further observed that the society was undergoing tremendous change unlike the one claimed in the popular official narrative of unity. He points out that handful of people dominated the larger cultural groups and perpetuated their cultural values at the ideological level. Bista points out:

The Nepali society at large remained fragmented because the society of expanded Nepal could not develop a system of melting pot process as the Kathmandu valley society of the Licchavi period had done. In course of time the fragmentation of the society began to affect the mind and the thinking process of the people. People got used to think in terms of very restricted small groups as their only reference of being their own people. $(1989$, p.176)

Apart from this he also explicitly mentions the social institution of afno manche, which caters to the sycophants around the ruler, where necessity and emotions are exchanged only among the selected groups creating the faultline of 'us' and 'them'. And this is rampantly found among the community members belonging to different groups, caste, ethnicity, creed and region. To quote Bista again:

But, it is true that outside of this circle Nepali individuals feel themselves and treat others almost like non-person. They care less for people without references. Only individuals belonging to one own circle of one kind or another are real human beings with flesh and blood. Naturally, there are exceptions to this rule. But increasing practice of favoritism and corruption in politics, administration and business shows the rule rather than the exceptions. (1989, p.178)

The idea of in-group in such set ups are determined by social hierarchy based on vertical order of caste and feudalism. On the basis of these variables corresponding cultural practices, values, 


\section{2| Gaurab KC \& Pranab Kharel}

customs and ethics were established and exchanged in Nepali society. These traits Bista stresses perpetuate the psyche of fatalism and action of the people which as a result discourage the hard working ethics and institutionalize the system of chakari?. Therefore, in the vertical hierarchical order the people who work really hard and are economically productive are at the bottom there lacks a mechanism which rejects corruption and chakari. For Bista, Chakari is all pervasive and is visible what chakariwalas do in the everyday life. This, he argues has also strengthened in institutionalizing corruption and hierarchy.

Bista argues that Chakari was institutionalized during the Rana regime and continues till this date. He conceptualizes it as

In the Hindu faith it is a perfectly legitimate word which means to wait upon, hang around, server, or appease for seeking favor from any god within the pantheon....The cakari was made official during the Rana regime. People, especially high official, were made to hang around for hours, sometimes four to five hours in Rana places to prove their loyalty still visible in Nepal. Many people have faith in Cakari than in work for promotion. It is, therefore, very difficult to teach people to work hard for progress. (2015, p.111)

Notably, Bista was not the first one to introduce the idea of Chakari as an institution in the Nepali academic landscape. Ludwig F. Stiller and Ram Prakash Yadav had substantiated the idea of Chakari during the late seventies in their book Planning For the People (1978). The authors' state:

Chakari was an informal social institution. There were no regulations governing chakari, but the unwritten rules were clear and only broken by the ill-advised. Chakari was the public sign of loyalty to one's immediate superior. It entailed attending on him, either at his home or office, where one was expected to render small services or to show appreciation for his superior's wit, wisdom or decisions. Chakari, of course, was something even non-office holders could perform. It was an ideal way to put oneself in line for possible assignment in line for possible assignment at the

9. The usage of the word chakari was earlier mentioned in the writings of scholars like Kamal Prakash Malla and Rishiskesh Shah . Bista has rather substantively elaborated it in his book. 
next pajani or to add insurance to the effectiveness of one's service record. From the point of view of the one doing chakari, it was both a sign of loyalty and currying a favor. The one receiving chakari simply recognized it as his due. Those who performed chakari were favored. Those who failed to do so or who seemed less appreciative were held in less esteem and were not favored when rewards were not passed out. (1978, p. 21)

The concept of Chakari was rooted in the psyche of the people who worked in the Panchayat bureaucracy. State institutionalized it as a social and cultural value in the everyday life.

\section{The Making of F\&D}

The article 'The Structure of Nepali Society reflects the ideas espoused by Bista in $F \& D$. Both these works also indicate the decade of transition and the position of Bista accommodating with the time and his personal transition concerning his academic shift. The scope and nature of developmental discourse manifested in a set standard and new avatar during 1980s. In this period Nepal had already witnessed the opening of floodgates of Western aid in the Nepali development discourse. The agendas were being set and defined by a handful of Nepali bureaucrats in consultation with the donor agencies. This in effect created a policy paradox wherein the Nepali reality was defined through the western lenses ${ }^{10}$. As he was affiliated to different aid agencies, Bista had to produce something new. So this book could also be understood as Bista's attempt to cater to his development constituencies.

Interestingly, his inclination towards the institution of Kingship remained the same. In his numerous writings Bista has highly admired and appreciated King Prithivi Narayan Shah, King Mahendra Bir Bikram Shah and King Birendra Bir Bkram Shah for their tireless effort and contribution in building and making the nation, bringing people into the unity framework, along with ushering in development and initiating the process of larger interaction of Nepal with the rest of the world. For him these leaders were the nation builders and true modernizers.

Bista, in fact, was against the value system as initiated and institutionalized by Malla Kings, Ranas and legitimized by priestly

10. See Pandey (2009) 


\section{4| Gaurab KC \& Pranab Kharel}

Bahuns. The authors have here forth placed Bista in his intellectual and social setting. This section of the paper informs the overall making of the book and look at some of his ideas in $F \& D$, such as Bahunbad ${ }^{11}$ and fatalism.

Unlike his book People of Nepal, many reviews and commentaries have been generated both for and against this book.

Bista started working on this book since mid-1980s and its typescript was completed in 1989. Compared to other scholars the production of Bista's scholarship was funded by various institutions from the very beginning. He was provided with financial grants in writing this book by different institutions. As acknowledged, Toyota foundation, Ford foundation, CNAS and Integrated Mountain Development (ICIMOD) were the major funders. Upon receiving the British Council Fellowship, he went to Cambridge University for three months. There he interacted with Ernest Gellner and Alan Macfarlane in developing the manuscript. Later on both Alan and his wife Sarah helped edit the final version when they were in Nepal in late 1980s. It was especially Sarah, who assisted him in editing in London. She recounts a memory how she benefitted in learning Nepali from Bista and in return how she helped him in editing the entire manuscript ${ }^{12}$.

Similarly, Bista was provided an additional grant by the Ford Foundation through which he went to the University of California Berkley for six months in 1989. There he received suggestions and feedback from Dev Raj Dahal, Krishna Bahadur Bhattachan and Leo E. Rose on improving the manuscript in the earlier stage. The manuscript was titled as Bahunbaad and it was Dahal who suggested him to change the title.

The original manuscript, however, is not even with the family. His son Kesar B Bista informed that Dor had taken the original manuscript with him in Chaudabisa, Jumla ${ }^{13}$. But, he was unaware whether his father carried the manuscript with him before he disappeared or was it with the library he set up in Chaudabisa which was incinerated by the Maoists during the conflict.

InF\&D Bista comes down heavily on the priestly Brahamins ${ }^{14}$

11. Bista argues that the Bahuns he is referring to are the ones who engage in priestly jobs and is not intended for the social group as such

12. Based on the interview dated 2011.

13. ibid

14. It is necessary to distinguish between three kinds of Brahamins (espe- 
in terms of propagating the values whom he has identified as the perpetuator of the fatalistic attitude by usurping the power relation inherent in society. Similarly, he is critical towards the administrative Brahmins and Chhetris in institutionalizing the attitude of Chakari and Aafno Manche in the people involved in the state bureaucracy. Bista goes on to add that the fatalistic attitude is responsible for the inertia set into motion with regard to the idea of achievement. The point being driven home is that the fatalistic attitudes are responsible for the lack of progress in the society. This in effect meant that then people would attribute both success and failure to some external and invisible force instead of relying on their own ability or lack thereof for instance, Bista's article 'Des Vikas ma Dharmik Biswas ko Asar' (1968) castigates people for adopting fatalistic attitude instead of participating in the development process. In the article Bista cites an instance he encountered in Eastern Tarai and links with the development discourse claiming to be a major setback for the gradual process of the development of the country. According to Bista, denizens there were more interested in attending a religious ceremony of reciting Bhagwat, a holy text book for caste Hindus, than get down with the development work. It is interesting to note that the participation in the recitation was intended to better the next life. It is therefore clear that Bista was building this perception throughout his career. And this was manifested in one or another way at different periods.

This points out that Bista was not arguing anything new than what he was stating in his previous writings. However, publication of $F \& D$ coincided with major changes in Nepal. This change will have to be placed within the larger changes occurring in the world. Late 1980s and early 1990s (when this book was published) witnessed a massive surge in the idea of ethnicity. Ethnic identities were being played out as major social, political and cultural categories around which identity-based politics would revolve. It is interesting to note that during the same period, marked by relative opening up in Nepal following the national referendum and people's movement, identitybased groups and organization had begun to assert themselves. This has been largely fueled further by the development organizations and the discourse they disseminated. As it can be seen that Bista was

cially in reference to those of hills) - priest, administrators, and peasant. This distinction will further help to distinguish between the existing social and political layers within the category of Brahmins. 


\section{6| Gaurab KC \& Pranab Kharel}

not offering new arguments in $F \& D$ to what he was stating in other writings, this indicates his ability to communicate same thing to different intended audience - the nationalists who were close to the palace, the intelligentsia and the members of development agencies. This capacity to communicate with different constituencies at the same time makes him a clever actor in the difficult situations. For instance, majority of works were penned by Bista in English. This despite the fact that English speaking population in Nepal until 1970's was miniscule. This can be taken as an indication of his ability to talk to small but powerful group of people operating in Nepali society including development expats and diplomatic community.

While Bista's argument in F\&D could be placed in its time, he offers no explanation as to why Nepalis, especially Brahamins and Chettris of whom he is very critical, want their children to acquire modern education and compete in the job market instead of resigning to their fate. In addition to this Bista also seems to ignore the changing contours of commensuality in the 1990s which were much more relaxed than the preceding decades.

\section{Conclusion}

Bista's F\&D is a book produced in the changed political context following the restoration of multi -party democracy in 1990. This book gives a glimpse into Bista's thinking of the time where he was conversant with different set of audiences ranging from the new emerging political actors including those involved in janajati politics to those associated with the fat cats of development. Bista's attempt to communicate with the janajati actors is reflective of the anthropological trend in Nepal after 1980s. In fact, the central argument of F\&D gave collective thrust to the janjati politics as it began to be played out after 1990. This was furthered by the fact that Bista no longer harped on the singular identity of Nepali as he was previously doing in other works. Also the fact that some of the major arguments presented by Bista in this work became musing to the Western development agencies provides hints to how book became donor darling. 


\section{References}

Bista, D. B. (1957). Ramailo Khumbu ra Kehi Sherpa Lok Git. Dafechari 6(5): 3-14.

Bista, D. B. (1958). Educational Problems in the Northern Border Areas of Nepal. Educational Quarterly 2(3): 98-102.

Bista, D. B. (1958). Report of an Educational Fact Finding Excursion to North East Nepal. Educational Quarterly 2(4): 157-163.

Bista, D. B. (1958). Jilla Parichaya- Solu Khumbu. Vikash 1(4): 28-31.

Bista, D. B. (1967). People of Nepal. Kathmandu: Department of Publicity, Ministry of Information and Broadcasting, His Majesty's Government of Nepal.

Bista, D. B. (1968). Des Vikashma Dharmik Biswasko Asar. Rup Rekha 8(9): 50-56.

Bista, D. B. (1971). Administration of Development Programs in the Himalayan Area. In Aspects of Development Administration. Prachanda Pradhan, ed., pp. 57-61. Kathmandu: Centre for Economic and Development Administration (CEDA), Tribhuvan University.

Bista, D. B. (1971). Frustration in Nepali Bureaucracy. In Aspects of Development Administration. Prachanda Pradhan, ed., pp. 33-39. Kathmandu: CEDA, Tribhuvan University.

Bista, D. B. (1972). Sabai Jatko Fulbari. Kathmandu: Sajha Prakashan.

Bista, D. B. (1978). Nepalese in Tibet. In Himalayan Anthropology: The Indo Tibetan Interface. James F. Fisher, ed., pp. 187-204. The Hague, Paris: Mouton.

Bista, D. B. (1979). Report from Lhasa. Kathmandu: Sajha Prakashan.

Bista, D. B. (1982). The Process of Nepalization. In Anthropological and Linguistic Studies of the Gandaki Area in Nepal (Monumenta Serindica 10). Dor Bahadur Bista, et al.,eds., pp. 1-20. Tokyo: Institute for the Study of Languages and Cultures of Asia and Africa.

Bista, D. B. (1985). Ethnicity: Its Problems and Prospects, unpublished report submitted to Centre for Nepal and Asian Studies.

Bista, D. B. (1989). The Structure of Nepali Society. In Nepal: 
148| Gaurab KC \& Pranab Kharel

Perspectives on Continuity and Change. Kamal P. Malla, ed., pp. 169-191. Kirtipur: Centre for Nepal and Asian Studies.

Bista, D. B. (2002). Sabai Jatko Fulbari. Kathmandu: Himal Books. (Introduction By Harka Gurung).

Centre for Nepal and Asian Studies (CNAS). (2015). Bibliography of Social Scientific Writings by Dor Bahadur Bista. In Anthropology of Nepal: A Compilation of Dor Bahadur Bista's Articles pp.138-142. CNAS: Kathmandu.

CNAS. (2015). Structure of Nepali Society. In Anthropology of Nepal: A Compilation of Dor Bahadur Bista's Articles pp. 99-119. CNAS: Kathmandu.

Dahal, D. R. (1990). Book Review. Fatalism and Development. Contribution to Nepalese Studies 17(1): 85-92.

Kamata, Y. (1999). The Implicit Mode of Domination in

Nepal: Fatalism and Bahunism as the Main Causes of

Underdevelopment. Contributions to Nepalese Studies (CNAS) 26(1): 65-81.

KC, G. \& Onta, P. (2013). Bibliography of Social Scientific Writings by Dor Bahadur Bista. In Anthropology of Nepal: A Compilation of Dor Bahadur Bista's Articles (version 3). Accessed at http://www.martinchautari.org.np/files/ DorBahadurBista-GaurabKC-POnta.pdf

KC, G. People of Nepal: Perspective, Retrospective and Reappraisal (unpublished).

Macfarlane, A. (1994). Fatalism and Development in Nepal. In Nepal in the Nineties: Versions of the Past, Visions of the Future. Michael Hutt, ed., pp. 106-127. Delhi: Oxford University Press.

Malla, K. P. (1979). An Intellectual in the Corridors of Power. In

The Road to Nowhere, pp. 171-178. Kathmandu: Sajha.

Malla, K. P. (1980). Introduction. In Nepal A Conspectus. Kamal

P Malla, ed., pp. I-V. Kathmandu: The Preparatory

Committee $26^{\text {th }}$ Colombo Plan Consultative Committee Meeting Kathmandu.

Malla, K. P. (1992). Bahunvada: Myth or Reality. Himal 5(3):2224.

Metz, J. (1996). Book Review of Nepal: Development and Change 
Dhaulagiri Journal of Sociology and Anthropology Vol.11, 2017|149

in a Landlocked Himalayan Kingdom ; Dor B Bista,

Fatalism and Development by P.P. Karan and Hiroshi Ishii.

Himalaya, the journal of the Association for Nepal and

Himalayan Studies XVI (1\&2): 47-52.

Pahari, A. (1992). Fatal Myth. A Critique of Fatalism and

Development. Himal 5(1): 52-54.

Pandey, D. R. (2009). Nepal's Failed Development: Reflections on the Mission and the Maladies. Nepal South Asia Centre:

Kathmandu.

Sharma, P. R. (1978 b.). Nepal: Hindu-tribal interface.

Contributions to Nepali studies (CNAS), 6(1): 1-14.

Sharma, S. (1991). "Book Review: Fatalism and Development".

Himalayan Research Bulletin XI(1-3): 139-141.

Stiller, L. F. \& Yadav, R. P. (1978). The Starting Point. In Planning

For People. Ludwig F. Stiller and Ram Prakash Yadav,

ed., pp. 1-27. Kathmandu: Human Research Development

Centre.

Uberoi, P., Sundar, N. \& Deshpande, S. (2007). Introduction: The

Professionalization of Indian Anthropology and Sociology-

People, Places and Institutions. In Anthropology in the

East: Founders of Indian Sociology and Anthropology eds., pp. 1-63. Ranikhet: Permanent Black.

KC, Gaurab (ORCID: 0000-0002-6066-4728) is an assistant professor at Kathmandu School of Law (KSL) and is a member of academic research in law school. He is also affiliated with Martin Chautari, a think tank research institute based in Kathmandu. His research interests include disciplinary history, intellectual biography, legal anthropology/sociology, migration, media, urbanization, street economy, violence and social movements. His academically published work includes Intersections in Managing Sociology in Management Studies: A Personal Reflection (coauthored with Pranab Kharel), Society and Culture in South Asia 4(1), 2017, An Interview with James F. Fisher, SINHAS 18(2), 2013, Kamaune: The Cultural and Economic Imaginaries of Migration (2014) and Lau Aayo Taja Khabar: Kathmanduka Hakarharuko Adhyanu, Media Adhyan (7), 2012

Email: gauravdoti@gmail.com 
150| Gaurab KC \& Pranab Kharel

Kharel, Pranab is Asst Professor teaches sociology including sociology of Law at Kathmandu School of Law (KSL). Research interest include state, law, globalization, social change, social institutions and disciplinary history among others. Kharel is also part of the research team at KSL working on identifying causes of torture and their customised solutions within security agencies in Nepal in collaboration with Nepal Police, Armed Police Force, Ministry of Forests and Soil Conservation in partnership with Danish Institute for Human Rights. Kharel has been teaching for almost a decade and has been regular contributor to English language daily Republica. In the past he was associated with another English language daily The Kathmandu Post in different capacities including senior reporter. Email: pranabkharel@gmail.com 